\title{
Home reading effective organization as independent work form during foreign language teaching in conditions of forced isolation
}

\author{
Marina R. Zheltukhina - Larisa L. Zelenskaya - Galina N. Ostrikova - \\ Ekaterina A. Redkozubova - Olga O. Chernova
}

DOI: 10.18355/XL.2021.14.01.19

\begin{abstract}
The article is devoted to the study of the effectiveness of organizing independent work in a foreign language lesson in high school using the example of home reading in a remote format in a situation of forced isolation. The situation with the coronavirus pandemic and forced isolation requires a rethinking of the process of teaching foreign languages, the adaptation of traditional methods and the development of new methods for remote work. The article discusses the importance of students' independent activities in the process of teaching a foreign language. The peculiarities of formation of communicative competence in the process of learning a foreign language are revealed. It describes the process of organizing home reading in English lessons, and analyzes the practical formation of communicative competence in the process of independent work in English lessons on home reading in a remote format. The specifics of the organization of home reading in the English language lesson at the level of basic general education based on the English Language educational and methodological complexes (EMC) (6th grade) and the tutorial Home reading is established. The theoretical significance of the study results is to replenish the idea of the effectiveness of the process of organizing home reading and the formation of communicative competence among secondary school students on the materials of home reading lessons in conditions of forced isolation. The practical value of the work lies in the analysis of a universal teaching manual for the formation of communicative competence in a remote format as part of independent work in English lessons for secondary school students in the aspect of home reading on the material of short stories.

Key words: independent work/study, self-work/study, foreign language lesson, English language lesson, communication competence, home reading, distance learning, forced isolation, pandemic
\end{abstract}

\section{Introduction}

The current situation in the world, involving the large-scale spread of various kinds of viruses that cause pandemics COVID-19, requires a rethinking of the learning process, the adaptation of traditional methods and the development of new methods for remote work during forced isolation. In connection with the new conditions of study, a large, almost the main place in the educational process begins to be occupied by the independent work of schoolchildren and students. These proposed circumstances also apply to the teaching of foreign languages. Home reading lessons are an important part of the learning process in foreign languages. When reading authentic texts, students meet with the real use of the language, and get the opportunity to express their opinion and form a life position regarding the issues raised in the works. At the present stage, in the methodology of teaching foreign languages there is no single structure for organizing home reading lessons, which requires special study and the development of universal lessons. In addition, the organization of independent work in foreign language lessons in the "home reading" aspect in a remote format during forced isolation was not previously studied. All this determines the relevance of our research.

XLinguae, Volume 14 Issue 1, January 2021, ISSN 1337-8384, eISSN 2453-711X 
The purpose of the study is to study the process of organizing home reading in high school as a form of independent work of students using the example of English lessons in conditions of forced isolation.

Research hypothesis: competent organization of work in the "home reading" aspect of English lessons in a remote format in conditions of forced isolation will allow students to form skills in independent work when mastering a foreign language.

The purpose of the work is to solve the following problems:

1. To consider the independent activities of students in the process of teaching a foreign language.

2. To reveal the specifics of the formation of communicative competence in the process of learning a foreign language.

3. To describe the process of organizing home reading in English lessons in high school.

4. To analyze the practical formation of communicative competence in the process of independent work in English lessons on home reading and establish the specifics of organizing home reading in an English lesson at the level of basic general education on the basis of the English Language teaching and methodological complex (6th grade) by O.V. Afanasyeva and I.V. Mikheeva (2018); educational and methodological complex "English in focus" ("Spotlight") (6th grade) by Yu.E. Vaulina et al. (2018), V. Evans, as well as the tutorial Home reading in five O. Henry's short stories by M.R. Zheltukhina, A.I. Pogonova and Yu.N. Khoruzhaya (2020).

The research question is "how effective is the organization of home reading in high school as a form of independent work of students using the example of English lessons in the distance learning format in conditions of forced isolation"?

The goal set determined the choice of the object and subject of the study.

The object of the study is an independent work in an English lesson.

The subject of the study is the organization of home reading as a form of independent work in the English language lesson at the level of basic general education in a distance format in conditions of forced isolation.

The scientific novelty of the study is that the work for the first time explored the possibilities of organizing home reading as a form of independent work in an English lesson on the materials of the EMC in order to form the communicative competence of foreign language students in high school, and offers an analysis of the universal method of self-study in English lessons in the aspect "home reading", which is presented in the universal tutorial on home reading by M.R. Zheltukhina, A.I. Pogonova and Yu.N. Khoruzhaya (2020), effectively used including in distance learning format in conditions of forced isolation.

\section{Literature Review}

To date, many studies have been devoted to the topic of independent work of students. The concept of "independent work" is interpreted ambiguously, and now there is no single definition of independent work of students. Consider how the term "self-work" is defined by some researchers dealing with this issue. G.M. Perova (1990) presents independent work in the form of completing tasks by students without assistance and with a controlling function of a teacher. This interpretation has long been criticized, since it was believed that the author underestimated the internal component of the student's independent work, which consisted in independent judgments, conclusions, and judgments. By independent work, following A.N. Shchukin (2015), we understand the mode of educational activity, consisting in certain educational tasks that are set for the student and provide a mental burden, and recommendations for their implementation. Independent work requires a mental load of students, is implemented without turning on the teacher, while under his leadership. 
Independent work in a foreign language as a type of educational activity allows students to make mental efforts when performing various tasks with or without the participation of a teacher, while demonstrating the skills and skills of self-control, self-correction (Konysheva, 2011). Considering the interpretation of various researchers, it can be concluded that each author has his own vision of determining independent work. Therefore, it is advisable to consider this type of educational activity, paying attention to its types, classification, and application.

Independent work is created by various types of collective and individual activities for students, which are carried out as part of the classroom and out-of-school work or at home on assignment without the participation of a teacher. The consideration of the independent activities of students is based on a general pedagogical definition of the concept of extracurricular and extracurricular work, according to which it is various types of educational activities that are organized and used by the school in extra-time (Maslyko et al., 2001). Mastering English or any other foreign language by developing in students lexical, spelling, grammatical, and other skills based on improving their perception of speech by ear, the ability to speak, read and write. Skills are developed only in the process of systematically performing certain actions with a training set of actions, which assume that the student will repeatedly listen, pronounce, read, and write in a foreign language (Bialystok, 2001). In independent work, it is necessary to include certain stages of work on the language: familiarization with it and partial development of its use. It should be noted that at this stage of the methods of teaching foreign languages, auditing tasks are suitable not only for working on lessons, without training, there are also audio texts for independent work of students at home. Teaching writing skills involve certain stages at which independent work plays a greater role than the work of a student in a class. Reading is of particular importance in the independent work of students. This type of activity is performed by the reader mainly alone, independent, independent work fully corresponds to it (European Commission, 2005).

When organizing the independent work of students, due attention should be paid to the following didactic requirements (Arkusova, 2012): 1) the main didactic tasks: obtaining solid knowledge, developing cognitive abilities, expanding and deepening knowledge, developing the ability to independently acquire and apply them in practice; 2) basic principles of didactics: basic principles of work and opportunity, conscious and creative activity, theory with practice, training at a high level; 3) a sequence of home and class work for preparation for subsequent work, resulting from previous independent work.

Independent work is divided into five groups on a didactic goal (Batyreva, 2017): 1) obtaining new knowledge, mastering the ability to independently acquire knowledge; 2) consolidation and clarification of the acquired knowledge; 3) development of the ability to apply knowledge in practice in solving educational and practical tasks; 4) formation of practical skills; 5) the formation of a creative character, the ability to know in difficult conditions. All these groups include several types of self-work, since the same didactic task can be used to enumerate the methods (Jacobs, 2008). It should be noted that the selected varieties of independent work on a didactic goal are very significant in conditions of forced isolation in the process of organizing remote work not only in foreign languages, but also in other disciplines. It should also be mentioned the classification of A.V. Konysheva (2008a), which identifies 4 types of independent work: frontal, group, paired, individual. At front work, students work independently, performing the same tasks. In group work, students work in small groups. In the process of paired work, students work in pairs and on proposed tasks. When organizing individual work, each student independently performs an individually prepared task. Group and pair work can be individualized and separated (Konysheva, 2008b).

XLinguae, Volume 14 Issue 1, January 2021, ISSN 1337-8384, eISSN 2453-711X 
Considering the above, we emphasize that the goal of home reading as a form of independent work in the study of a foreign language is the implementation of a pedagogical task, namely: the education of a culture of independent work and the formation of a methodology for the development of speech skills in the study of language material (Konysheva, 2005; Vishnyakova, Pyatkina, 2019). The teacher's task is to select the content of training, rational organization of independent work. Now, it has been proved that the excessive activity of the teacher in the transfer of knowledge, in detailed explanations, often leads to an inhibition of the perception of material by students (Stack, 2003). The independent work of students implies their maximum activity in relation to the subject of the studied activity, in the specific case of reading in a foreign language (Kulagina, Kolutski, 2009). Independent work implements a variety of activities of students of an educational and educational nature at home and at school (Shatilov 1986). The main purpose of home reading is to obtain information from texts in a foreign language. At the same time, system and systematic home reading is important for the replenishment of vocabulary and the development of student speech skills (Wong, 2014).

So, the organization of home reading in English lessons is one of the most important conditions for developing the skills of students to work independently. During the study, it was determined that the self-study activities of students play a large role in teaching a foreign language, and home reading in turn contributes to the development of the self-work of students. Independent work refers to various types of individual and group activities of students in classroom and extracurricular classes or at home on tasks without the direct participation of the teacher. Considering the interpretation of the term of independent work of various researchers, we can conclude that each author has his own vision of the definition of this term, we have deduced a universal definition of the concept. Independent work as a collective and individual activity palette of students is carried out by them in the classroom and out-of-audience work at school, as well as at home on assignments without the direct participation of the teacher.

In the modern world, knowledge of foreign languages plays an important role. Knowledge of a foreign language allows the younger generation to be closer to the world culture, to use the great potential of resources in their future professional activities, to work with information and technologies, as well as multimedia education (Lado, 1964; Aleshchanova, Frolova, Zheltukhina, 2019; Zheltukhina, Zelenskaya, Ponomarenko, 2020). In the context of the transition to FSES, it is safe to believe that the role of foreign languages in the formation of basic competencies is rapidly increasing (Batyreva, 2017). This is due to the expansion of foreign economic relations, an increase in the number of enterprises working with foreign partners, as well as the large use of imported technologies. Thus, in the modern world, there is a growing need for specialists (Batyreva, 2017) with knowledge of a foreign language who can conduct effective professional activities.

Communicative competence is understood as a readiness for verbal and non-verbal interaction (facial expressions, body language) with other people (Hornby \& Wehmeier, 2004; Zheltukhina et al., 2017; Tameryan et al., 2019). The formation and development of communicative competence involve the comprehensive improvement of its components (Galskova, 2003; Afanasyeva, Mikheeva, Yazykova, 2012):

1) speech competence: improving communication skills in such types of speech activities as reading, writing, auditing, speaking, the ability to plan verbal and nonverbal behavior;

2) language competence: systematization of previously studied material, development of skills of application of language units for communication purposes;

3) sociocultural competence: increase of knowledge about sociocultural characteristics of English-speaking countries; 
4) compensatory competence: development of skills to get out of the situation in case of insufficient language means in the process of obtaining and transmitting information in a foreign language;

5) educational and cognitive competence: the development of general and special educational skills to increase the effectiveness of educational activities in learning English.

A communicative approach is an opportunity to implement such a method of teaching, in which the systematization and the teaching of a foreign language are carried out as a means of communication (Thyne, 1963). The basic principles of teaching using a communicative approach (Passov, 1985; Sheils, 2001; CEFRL, 2002; Kalistrova, 2003; Kozyreva, 2008; Kolesnikova, Dolgina, 2008; Wachter, Maiworm, 2008; Asimov, Schukin, 2009; Kitaigorodskaya, 2009; Bukovsky, 2012; Altun, 2012; Lyapko, 2016) are:

1. Communicative orientation of speech. Learning foreign languages through communication. This implies a practical orientation of the lesson. In the process of learning, only foreign language lessons, and not about it. You can only learn to speak a lot by listening and reading. First, this concerns exercises: the more the exercise looks like real communication, the more effective it is. In speech exercises, there is a smooth, dosed, and rapid accumulation of a large amount of vocabulary and grammar with immediate application; phrases that cannot be used in real communication are not allowed.

2. Speech functionality (phonetic, lexical, grammatical) during conversation. Therefore, words cannot be remembered in isolation from the forms of their use. Functionality assumes that words and grammatical forms are learned directly during the lesson process.

3. Situationality. It is very important to select and organize materials based on situational communication.

4. Novelty in different components of the lesson: in the context of speech situations (changing the topic of conversation, discussion problems, speech opponent, communication conditions); in terms of the materials used (their informativity), within the framework of the organization of lessons (their types and forms), in methodological diversity. In such cases, students do not receive direct indications of memorization - it becomes a by-product of speech activity with material, this is called involuntary memorization.

5. Personal orientation of communication. There is no faceless speech. Speech is always individual through natural properties (abilities), including the implementation of educational and speech activities, and personality characteristics: experience, context of activity (an individual set of activities based on relationships with other people), feelings and emotions (one has pride in his homeland, and the other has no), interests, status (position) in the group. Communication training involves considering all these personal characteristics, because this is the only way to create conditions for communication in society.

6. Collective interaction as a way of organizing the educational process, in which students actively communicate, and the success of other team members is a condition for the success of each of them.

7. Modeling of country science and linguistic knowledge. Due to the large amount of information, it is difficult to reach it when studying in high school. Therefore, it is necessary to choose the amount of knowledge that will be necessary to have an idea of the country's culture and language system in a concentrated, model form.

The level of secondary general education implies the basic skills of communication in a foreign language, which allows us to consider a foreign language (English) not so much as an object of study, but as an instrument of communicative interaction in society.

XLinguae, Volume 14 Issue 1, January 2021, ISSN 1337-8384, eISSN 2453-711X 
The communication principles described make it possible to effectively build the process of teaching a foreign language in high school by using appropriate teaching methods and means.

In the context of the transition to FSES, we can confidently believe that the role of foreign languages in the formation of basic competencies is rapidly growing. Particular attention is paid to communicative competence as a readiness for interaction, verbal and non-verbal (facial expressions, body language), with other individuals. The formation and improvement of communicative competence take place taken together of all its components in accordance with speech competence, language competence, sociocultural competence, compensatory competence, educational and cognitive competence.

Home reading as an independent aspect of foreign language learning plays a decisive role in the formation of reading and speaking skills using computer technologies (Shapovalova, 2010) in the new conditions of distance learning. Independent reading of foreign language literature and its discussion is an integral component of the process of teaching a foreign language in a modern digital environment.

\section{Methodology}

The methodological basis of the work is a systematic approach, which includes a system-complex, system-structural, and system-functional approaches.

The following research methods were used in the process of conducting the study: analysis of pedagogical and methodological literature on the topic of research, a descriptive and analytical method, a method of comparison, a method of generalizing and systematizing the selected material, a combined method, a definitional, interpretive analysis.

The work relied on the theoretical works of Russian and foreign authors in the field of independent work, teaching foreign languages, developing reading skills, forming communicative competence (Perova, 1990; Galskova, 2003; Passov, Kuznetsova, 2002; Katzman, 2003; Galskova, Gez, 2007; Kulkina, 2007; Kozyreva, 2008; Rogova, Vereshchagina, Yazykova, 2008; Kitaigorodskaya, 2009; Beem, 2011; Konysheva, 2008b; 2012; Schukin, 2015; Hakuta, Butler, Witt, 2000; Wong, 2014; Jacobs, 2008; Wachter, Maiworm, 2008).

The study material in this work was the English Language Educational and Methodological Complex (6th grade) by O.V. Afanasyeva and I.V. Mikheeva (2018); educational and methodological complex "English in focus" ("Spotlight") (6th grade) Yu.E. Vaulina et al. (2018), as well as the tutorial Home reading in five O. Henry's short stories by M.R. Zheltukhina, A.I. Pogonova and Yu.N. Khoruzhaya (2020).

The theoretical significance of the research results is to replenish the idea of the effectiveness of the process of organizing home reading and the formation of communicative competence among secondary school students based on home reading fiction lessons in conditions of forced isolation. Comparative analysis of the English Language educational and methodological complex (6th grade) by O.V. Afanasyeva and I.V. Mikheeva (2018); educational and methodological complex "English in focus" ("Spotlight") (6th grade) by Yu.E. Vaulina et al. (2018), as well as the tutorial Home reading in five O. Henry's short stories by M.R. Zheltukhina, A.I. Pogonova and Yu.N. Khoruzhaya (2020).

The practical value of the work is the analysis of a universal teaching manual for the formation of communicative competence in a remote format as part of independent work in English lessons for secondary school students in the aspect of home reading on the materials of $\mathrm{O}$. Henry's stories.

\section{Results and Discussion}

In the modern method of teaching foreign languages, reading has become more important, and it has become an important role in the formation of language skills. 
Previously, reading in the foreign language teaching system received less attention. It was believed that reading is only the source of new words included in the vocabulary of the student, and the starting point for many dialogical and monological statements (Galskova, Gez, 2007). However, in the modern methodology, reading began to be perceived as one of the main goals of learning - a source of new intellectual and aesthetic information that can significantly enrich the student's personality if the ability and habit to use this source is developed in the course of learning (Gez, Frolova, 2008).

Today methodologists depending on the setting of the task distinguish four types of reading: viewing, orientation, studying and searching. All four types of reading are part of the foreign language curriculum (Katzman, 2003).

Viewing reading as a cursory, selective reading gives a general idea of the topic and issues that are raised in the text. Reading of the text is done fragment by fragment for detailed familiarity with the accented parts and details (Hakuta, Butler, Witt, 2000; Kiskina, 2017).

Orientation reading is cognitive reading, in which all speech work (book, article, story) becomes the subject of the reader's attention without the intention to obtain certain information. This is a read "for yourself," without a prior special setting for the subsequent use or reproduction of the received information (Bim, 2017).

Studying reading as thoughtful and slow reading contributes to a more accurate and complete understanding of text information, and its correct interpretation, implements a focused analysis of the content of the text, based on the linguistic and logical connections of the text (Verevkina-Rakhalskaya, 2007; Listopad, 2009; Bim, Shchepilova, 2010).

His task is to form the student's ability to independently overcome the difficulties of understanding a foreign text. The object of such reading is information contained in the text, and not linguistic material.

Speaking about search reading, it should be noted that it is focused on reading newspapers and literature by specialty. Its goal is to quickly find quite certain data (facts, characteristics, descriptions, numerical indicators, instructions) in the text and in the array of texts (Passov, Kuznetsova, 2002).

Home reading includes the listed types of reading, is mandatory for students, additional to the textbook to obtain the necessary information and develop certain communication skills.

In the way of reading, home reading acts as reading in itself or in an ideal form as visual reading is mature and the most perfect reading (Galtsova, 2004; Ostrikova et al., 2018). On the one hand, this helps to develop the skills and skills to read literature in a foreign language, and on the other hand, to develop the skills and skills of speech and writing. The main purpose of home reading is to obtain information from texts in a foreign language. At the same time, system and systematic home reading is an important source and means of increasing the vocabulary and developing the oral speech skills of students (Schukin, 2014).

There are two options for home reading: individual home reading, that is, when each student is working on his/her own text chosen by him/her or his/her proposed teacher according to his/her interests, home reading in the classroom, that is, when reads the whole class common to all text, but with different tasks and attitudes to reading depending on the language capabilities of students (Rogova, Vereshchagina, Yazykova, 2008).

In home reading lessons, two main elements of working with text should be sought: checking the understanding of what has been read, developing oral speech based on what has been read (monologue, dialogue, discussion) (Selivanova, 2003).

XLinguae, Volume 14 Issue 1, January 2021, ISSN 1337-8384, eISSN 2453-711X 
Home reading classes consist, as a rule, of three stages: the "Pre-text stage" (preparatory); "Text Stage" (work on the current excerpt); "Post-text stage" (final) (Coyle, Hood, Marsh, 2010).

The purpose of the first stage of work on the text: to provide students with preliminary information about the text: about the writer, time, and anera in which the described events take place; about the idea of the book to arouse the interest of students in the book, help them quickly navigate its content and eliminate the difficulties that may arise when reading.

At this stage, the instructor can apply such types of work as an introductory conversation, questions to students with the task of correctly understanding the received information (Afanasyeva, Mikheeva, 2014).

The task of the second stage is difficult. This, on the one hand, is an understanding of what has been read and deepening, checking the correctness of the student's conclusions and his ability to understand the content and give a critical assessment. On the other hand, it is necessary to teach utterance based on the text, as well as to develop the ability to actively use this material not only when transmitting this content, but also when expressing thoughts about what has been read and in general in any situation of verbal communication (Fokina, Ternova, Kostycheva, 2009).

The second stage of work on the book consists of discussing certain passages of books and exercises aimed at fixing language material. At this stage, such types of work are used that simultaneously provide, and teach understanding and speaking (Schukin, 2014).

When compiling exercises, the type of speech activity (reading and speaking) and the functioning of language material in each of these types are considered, while it is difficult to draw a clear border between exercises aimed at understanding the text and exercises aimed mainly at speaking (Selivanova, 2004).

After discussing the book in parts, another, third stage of work is needed. This stage is necessary for repeating the completed vocabulary and controlling its absorption, as well as for discussing the entire book. It is planned that in the third stage, the students will be prepared to write an essay on the read text (Wiiley, 2005).

To better learn the text and control understanding, tasks are divided into two parts: separate tasks for independent homework of students and tasks for class working. Lessons should take time to test home exercises, but with some interpretation (Van \& Trim, 2001).

It should be noted that if home reading is introduced at the initial stage of training, the lexical material of the selected book should be reduced to the required minimum (Pavlenko, 2003).

The teacher's work in the home reading lesson begins with the selection of literary material. Further work results largely depend on his right choice. When choosing the following characteristics of students: their interests, determined by age, cultural level; degree of language proficiency (Rabinovich, 2012).

Literary material should be interesting for students, accessible for understanding, but at the same time not be primitive. As such material, it is more advisable to choose short stories, stories or stories divided into separate chapters. In the lesson, you can consider all types of selected literary works, conduct all types of work on each selected material (Polat et al., 2001).

The main requirement for reading texts is their accessibility to students. However, the strength of the text does not mean ease. Excessive facilitation of the text reduces its educational value (Solovova, 2005).

Another important requirement for texts is the requirement for the educational value of the text. The educational value of the text means its educational, educational, and useful value. The selection of texts will vary depending on the stage of training. So, at the initial stage, you need to give only entertaining texts; it is better for middle and senior to give entertaining and cognitive texts (Schukin, 2013). It is strongly 
recommended to use informative texts, bearing in mind that what defines the text from the point of view of communicative value is the information contained in it (Skatkin, 2002; Zelenskaya et al., 2018). Artistic texts have long been used for home reading in a foreign language in high school, the mechanism of their selection for use in home reading has firmly entered the practice of teaching foreign languages in secondary schools. At the same time, the search for rational ways to organize the selection of artistic material continues (Milrud, 2007).

It is advisable to consider reading at school as an independent type of activity, where reading "to yourself" should occupy a special place to extract information from readable texts (Obukhova, 2011).

At present, this problem can be successfully solved based on authentic texts of linguistic and cultural content. The legality of such texts is explained, first, by the increased interest and enthusiasm of students. In this case, it refers to informative reading, which, as you know, is intended to solve wider cognitive problems (Rabinovich, 2006).

At the initial stage of training, when students begin to get acquainted with the vocabulary and grammar of the language being studied, not every authentic text can be used in training. In this regard, it is advisable to use or adapt authentic texts. To create an educational text that is as close as possible to authentic, it is necessary to focus on the national traditions of building a speech work (Passov, Kuzovleva, 2011). The study of the language is inseparable from acquaintance with the culture of the countries in which this language is spoken, with the peculiarities of the life and mentality of their citizens. Without this, it is impossible to fully communicate with foreigners. Modern textbooks are full of local history information. In the process of working on such texts, students receive reliable language information (Sysoev, Evstigneev, 2014).

Texts telling about the history of the country of the language studied, about its capital, about its traditions and holidays, etc., expand the disciple's outlook and, at the same time, are a means of teaching the language (Kolesnikova, Dolgina, 2011). Learning other people through language is one of the important contacts of dialogue with the modern world. The achievement of cultural authenticity of educational texts allows us to effectively solve two main tasks facing a teacher of a foreign language: language education and cultural education (Shcherba, 2003).

Any text should contain new information which, in the author's opinion, would be of interest to the intended recipient. This requirement applies to the educational text: its content is selected in accordance with the age characteristics and interests of students, information is evaluated in terms of significance for students and accessibility. The text can be informatively authentic if it arouses a natural interest among the reader or listener. The choice of vocabulary and phraseology plays a role in achieving the reliability of the statement.

Authentic text is an excellent material for studying the phraseology of the language studied and working on it. Interlanguage inconsistencies are particularly important for specific examples. Thus, phrasal verbs are widely used in English (Colker, 2000). They cause difficulties among Russian-speaking schoolchildren and therefore are little represented in school textbooks. However, real English speech without these verbs is almost impossible. In addition, can a verb be considered assimilated, which the student understands only in one context. Therefore, it is advisable at an early stage of introducing previously studied verbs with prepositions into texts for home reading (Mukhina, 2012).

The correct selection of phraseologisms is of great importance for achieving the authenticity of educational texts. Familiarity with proverbs and phraseologisms forms the skills of students in authentic speech behavior, and the comparison of English and

XLinguae, Volume 14 Issue 1, January 2021, ISSN 1337-8384, eISSN 2453-711X 
Russian phraseology invariably provokes an emotional response and increases interest in the subject (Milrud, Goncharov, 2003).

The use of popular science and other popular science literature for reading is unproductive. It should be noted that the interest in reading popular science literature is unstable and very individual. This is primarily due to the specifics of the popular science genre, the narrow focus of its impact. Popular science literature is characterized by knowledge of certain aspects of reality (Kolkova, 2006). The perception of such literature requires a certain level of background knowledge, a special attitude, while the information contained in the work of art does not depend to the same extent on the reader's willingness to perceive the text.

When reading popular science and other popular science texts as part of home reading, adolescents are sometimes guided by formal motives, which is due to the lack of formation of a cognitive motive for reading in their native language. Artistic and non-artistic texts, as you know, differ between themselves and in-language features, namely the features of the choice and use of linguistic means (Dornyei, 2001; Kulkina, 2007). So, teaching a natural living language is possible using materials taken from the life of native speakers or compiled considering their culture and mentality in accordance with accepted speech norms (Kuzmenko, Rogova, 1999).

Methodologically reliable text is a natural speech product created for methodological purposes. You should simulate immersion in the natural environment in a foreign language lesson. When selecting texts for home reading, emphasis is placed on the literary and regional approaches as the only way to preserve all components of authenticity in reading material (Kukushin, 2005).

Home reading as a form of independent work in the study of a foreign language is aimed at solving the main tasks of the teacher - to educate the culture of independent work and form a tendency to develop speech skills when mastering language material among students.

Under home reading, you should take the form of organizing extracurricular work, in which students read the recommended texts outside time, as well as during the class without the direct help of the teacher.

Currently, methodologists distinguish four types of reading: search (reading aimed at quickly finding certain data in the text); viewing (obtaining a general view of the text); Evaluation (reading without a specific installation) studying (full understanding of all the information contained in the text). Home reading combines all four types of reading.

There are two types of home reading: general-class (the same text for reading, intended for the whole class and subject to general-class discussion) and individualized (each student works on his own, chosen by him or his suggested teacher in accordance with his interests, text).

Home reading lessons include three stages: Pre-text (preparatory), Text (work on the current passage), Post-text stage (final).

The fundamental requirements for reading texts are: accessibility, informative value, compliance with the language level and psychophysiological characteristics of age.

We describe the practical formation of communicative competence in the process of independent work in English lessons on home reading, including in a remote format in conditions of forced isolation.

We will describe and analyse the process of organizing home reading in English lessons at the level of basic general education based on the English Language EMC (6th grade) O.V. Afanasyeva and I.V. Mikheeva (2018); EMC "English in focus" ("Spotlight") (6th grade) Yu.E. Vaulina et al. (2018), Home reading in five O. Henry's short stories by M.R. Zheltukhina, A.I. Pogonova and Yu.N. Khoruzhaya (2020) on the materials of the stories of O. Henry in English: The Gift of the Magi, Soapy's Choice (The Cop and the Anthem), A walk in Amnesia, No Story, The Last Leaf. 
Analysis of the book for reading (Reader) EMC "English language" (6th grade) O.V. Afanasyeva and I.V. Mikheeva (2018)

EMC "English Language" for 2nd-11th grades is included in the Federal list of textbooks recommended by the Ministry of Education and Science of the Russian Federation for use in schools and classes with advanced study This EMC meets the requirements of the Federal State Educational Standard.

The composition of the EMC "English Language" (6th grade) O.V. Afanasyeva and I.V. Mikheeva (2018) included: textbook; audio course to the textbook; workbook; Audio course for the workbook Vocabulary and grammar workshop, book for reading; a book for the teacher; control tasks, a collection of exercises "Grammar of the English Language" by Barashkov E.A., Training exercises for preparing for MSE (OGE), Book for Parents.

Each educational situation is followed by a reserve lesson and a home reading lesson based on the lexical and grammatical material of the educational situation being studied. The reading material of the book corresponds to the topics in the tutorial. The textbook consists of 21 units, which correspond to 15 lessons for home reading. The entire material is located in two large sections - the main (mandatory) part and the part containing stories for additional reading (Supplementary Material). The EMC assumes that students themselves perform the texts and tasks for them at home, and in the lesson, there is a discussion of what was read and an analysis of the tasks performed. "Reader" is equipped with keys to tasks so that students can independently check their tasks. The mini-dictionary is not attached to the book, but there are pageby-page comments on each page, which significantly reduces the difficulties associated with understanding the material.

Each lesson includes: text (2-3 pages in middle font), 6-7 tasks and the section "Let Us Widen Our Scope," which should be offered to students who are especially interested in learning English. This section expands the outlook of students and introduces the topic in more detail, but it includes authentic texts and tasks, which causes significant difficulties. This section provides additional information that is thematically related to the educational situation. The informative material of the subsection in the form of complex, few adapted original texts is mainly countryscientific in nature, cognitive and interesting, preparing students for the corresponding work on reading in the 7 th grade. The teacher offers this section for independent work, since working with texts contributes to solving such problems as preparing students to work with a bilingual Anglo-Russian dictionary; developing their interest in the topic under study by reading materials as close as possible to the original; enlargement of their horizons and erudition.

To control the understanding of texts, their short retelling in Russian is used to devote a little time to this in the lesson. This section in the workbook is not accompanied by tasks.

The "Supplementary Material" section consists of texts of poetic and prose genres, which are offered for self-reading in the form of additional tasks and during the holidays.

Each of the 15 mandatory home reading lessons offers fabulous text, exercises to discuss it, such as:

- Put the sentences in the right order.

- Correct the statements.

- Answer the questions.

- Explain why: “....”

- Prove that: "...."

- Try and illustrate the proverbs with the help of the text.

XLinguae, Volume 14 Issue 1, January 2021, ISSN 1337-8384, eISSN 2453-711X 
- Say "True" "False" "I don't know".

- Add more details to: "..."

- Comment on: “...."

- Answer the question asked before reading the text, etc.

In our work, we analyzed EMC "English" (6th grade) O.V. Afanasyeva and I.V. Mikheeva (2018) for the organization of home reading. We have drawn the following conclusions: this EMC includes a variety of texts for reading and tasks for them; Each learning situation is completed with a home reading lesson; in the Reader home reading book, there are all stages of working with text, namely: "Pre-text stage" (exercises to predict the content of the read), "Text stage," "Post-text stage" (exercises to reconstruct the text, exercises to paraphrase, exercises to summarize the material, exercises to transfer the plot, exercises to compile character characteristics, exercises to find specific information).

The entire material of the manual corresponds to the topics of the program and the age of the students. Thus, a book for reading from this EMC is well suited for home reading as part of a school and additional program.

Analysis of the reader book of the Spotlight EMC. (6th grade) Yu.E. Vaulina et al. (2018).

The EMC includes: textbook; workbook; a book for the teacher; a book to read; language portfolio, $\mathrm{CD}$ for classroom work; $\mathrm{CD}$ for self-work; Website course (companion website) www.spotlightonrussia.ru; Checklist.

This EMC is the products of the Russian publishing house Enlightenment and the British publishing house Express Publishing, which reflects traditional and modern Russian and foreign methodological approaches to teaching a foreign language. EMC meets the requirements of the Federal State Educational Standard for General Education, Council of Europe Standards, Common European Framework of Reference.

The Reader book in the "English in focus" (6th grade) EMC is used as a mandatory component when working on each module. But based on the planning and the number of hours of learning a foreign language in a particular school, Reader can be used optionally.

Traditionally, the EMC "English in Focus" uses works of classical literature as reading materials. In EMC for 6th grade, this work was the story of L. Carroll "Alice in Wonderland".

The text of the story is adapted in accordance with the level of language training of students.

The reading book includes:

- Content;

- Biography of the author of the novel Lewis Carroll (in English);

- "Background" section (preface);

- "The plot" section;

- "The Characters" (characters and their description);

- 10 episodes (according to the number of class 6 program modules);

- "Activities" module consists of: the section "Before you start" (tasks for the sections Biography of the author, Preface, content, characters) and tasks for 10 episodes, the tasks for each of which are divided into three parts: "Before reading,"

"While reading" and "After reading";

- Final compensation quiz;

- Irregular verbs (a table of irregular verbs that were found in the text of the work);

- Glossary (dictionary, indicating the page on which the word met);

- Songs (songs).

- Also attached to the book for reading is audio accompaniment, which is an audio performance with expressive musical design. 
The volume of each episode is calculated to work during the lesson, considering the completion of the complete set of tasks for the texts:

- Before reading is aimed at predicting the meaning of text using illustrations, keywords, or suggested hypotheses.

For example, tasks such as:

1. Look at the pictures and the titles. How are they related?

2. Look at the subheadings for the episode. What do you think the episode is about? Listen, read and check.

3. Look at the pictures and answer the questions. Etc.

While reading is aimed at controlling the understanding of the text. Tasks such as:

1. Read and correct the words in bold.

2. Put events in the correct order.

3. Read and answer the questions.

4. Complete the sentences. And others.

After reading, tasks are aimed at controlling the understanding of the text, the development of speech skills and the development of skills for situational application of the language.

The subsection includes tasks such as:

1. Answer the questions.

2. Discuss in pairs.

3. Tell the class about ... And others.

Each page of the text is illustrated to develop forecasting skills and effectively organize speech activities based on what has been read.

The content of the story is the basis of the play, which is recommended for production at the end of the school year. The script and recommendations for staging are in the book for the teacher (p. 156). The music part, songs are offered in the audio application.

The study analyzed the process of organizing home reading on the material "Spotlight" (6th grade) by Yu.E. Vaulina et al. (2018). During our analysis, we have reached the following conclusions. The book for reading EMC meets the requirements of SES, the volume of each section of the manual is calculated to work for one lesson, considering the completion of a complete set of tasks for texts. Each page of the story is accompanied by illustrations that are supposed to develop forecasting skills and effective organization of speech activities based on what has been read. In the home reading book "Reader" there are all stages of working with text, exercises on forecasting, control of what has been read, exercises of a debating nature. Thus, it should be noted that the reading book is excellent for conducting home reading lessons at the level of basic general education.

The described options for organizing the process of home reading in high school can be used in conditions of forced isolation, but methods for using them in a remote format have not yet been developed. Next, consider a tutorial designed to improve the efficiency of home reading as a form of independent work in English lessons, which is applicable in a remote format, which has shown the practice of using it in secondary school in conditions of forced isolation.

Tutorial for Building Communicative Competence in English Lessons

As part of the study, a universal textbook was developed and analyzed (Zheltukhina, Pogonova, Khoruzhaya, 2020) for conducting home reading lessons in English at the level of basic general education based on the stories of O. Henry (2013). This manual is aimed at students in 5th-9th grades, depending at the level of training of students.

The manual consists of 5 stories adapted for the "elementary" level in English by the famous American writer O. Henry (2013), namely: The Gift of the Magi, Soapy's Choice (The Cop and the Anthem), A walk in Amnesty, No Story, The Last Leaf. The stories are divided into two parts.

XLinguae, Volume 14 Issue 1, January 2021, ISSN 1337-8384, eISSN 2453-711X 
Each part is accompanied by a preliminary vocabulary and tasks for a detailed analysis of the work.

The tutorial also includes sections such as Biographic Corner, which contains the most interesting biographical information about the author and Project Work, in which students can show creative skills and expand their horizons.

The main emphasis in this tutorial is on the independent work of students, which increases the effectiveness of forming the communication competence of students. Self-work skills come to the fore in a distance learning format, which is especially important for competently building the process of teaching foreign languages during a period of forced isolation.

It is assumed that texts for reading and task (or part of the task, at the discretion of the teacher) will be prepared independently at home, as well as during an online class, and then control in the classroom online or offline. The reading book is equipped with keys, which provides the possibility of self-testing if necessary.

Here is a piece from the tutorial.

O. Henry (2013). A walk in Amnesia

Mr. Bellford is a hard-working Denver lawyer who suffers an attack of amnesia. He becomes Edward Pinkhammer and starts to have a wonderful time in New York. His wife and his old friend Dr. Volney trace him and tell him who he is. He decides to try and remember. But he did have a wonderful time!

\section{Activities:}

Task 1 . Cover the words (vocabulary) and find them in the text. Highlight the words in the extract like in the example.

'I must have a name!' I looked in my pockets.

Task 2. Compose 5 sentences using the words.

Vocabulary...

O. Henry. A walk in Amnesia

Part 1

Activities:

Task 3. Answer the following questions:

Task 4. Describe:

1. A typical Mr. and Mrs. Bellford's morning and weekends;

2. Mr. Bellford's felling after he realized that he didn't know who he was.

3. The life of Edward Pinkhammer.

Task 5. Find English equivalents from the text to the following:

Task 6. Match the words from the lines to make the word combinations (used in the extract) and translate them.

Task 7. Rewrite the words in the right order to make sentences.

hard a people who work tired too lot hard get very of.

Biographical corner

Do you know that?

1. There is an annual festival in honor of O. Henry. Every May, people join together to celebrate $\mathrm{O}$. Henry.

O. Henry. A walk in Amnesia

Part 2

Activities:

Task 1. Cover the words (vocabulary) and find them in the text. Highlight the words in the extract like in the example.

'Give me my bill,' I said to the man behind the desk.

Task 2. Compose 5 sentences using the words.

Vocabulary...

Activities:

Task 3. Answer the following questions. 
Task 4. Say "True", "False" or "Not stated".

Task 5. Write down five words from the extract which contains the following sounds.

Task 6. Circle the one odd-out word, explain why.

Task 7. Find English equivalents in the text to the following.

Project work: Work in groups. Find out what is Amnesia. Give a short presentation. Then make a quiz about human's memory.

So, the textbook under consideration for conducting home reading lessons at the main level of general education is universal in nature, combining the independent work of students at home and online and offline in the lesson, their self-control by keys and the control of the teacher in the lesson, including in a distance format. The materials for creating a book for home reading were adapted versions of the stories of the famous American writer O. Henry: The Gift of the Magi, Soapy's Choice (The Cop and the Anthem), A walk in Amnesty, No Story, The Last Leaf, adapted to the level of proficiency in English, corresponding to students Each story is divided into two parts, which are accompanied by a vocabulary and tasks for detailed work on the works, on the author's biography, for project work on additional material.

\section{Conclusion}

1. Independent work when learning a foreign language as an acquaintance with language material and partial training in its use is carried out in various types of individual and collective activities of students in classroom and out-of-audience classes online or offline with a controlling function of the teacher or at home on tasks without the direct participation of the teacher.

2. The formation and improvement of communicative competence in English lessons online or offline as an ability and readiness for verbal and non-verbal interaction with other individuals in English takes place taken together of all its components in accordance with speech competence, language competence, sociocultural competence, compensatory competence, educational and cognitive competence.

3 . Home reading as a form of independent work in the study of a foreign language contributes to solving one of the main tasks of a foreign language teacher: to educate the culture of independent work and through it to form a methodology for developing communicative competence when mastering a foreign language, which is especially important and effective in conditions of forced isolation when switching to a distance learning format. The success of this educational process depends on the teacher's correct choice of literary material (cognitive and appropriate to the age, interests of students and the degree of their proficiency in the language) and on the consistent implementation of the preparatory (message with preliminary information about the book and the author), the main (work on the current passage of the book) and the final (systematization of the main ideas and thoughts on the book) stages of work in English lessons on the aspect of "home reading".

4. Analyzed books for home reading "Reader", which is part of the EMC "English Language" (6th grade) by O.V. Afanasyeva and I.V. Mikheeva (2018), and included in the EMC "English in Focus" ("Spotlight") (6th grade) by Yu.E. Vaulina et al. (2018), developed according to modern standards of foreign language instruction, rich in a variety of texts and tasks for them, suitable for home reading as part of a school and additional program. Both books differ in the scope of all stages of work with text, temporal, thematic and age correspondence, and a set of exercises for texts. The first book is aimed at improving the understanding of the text, a more detailed analysis of lexical and semantic units, replenishing the lexical reserve of students, developing their interest in learning English by reading materials as close as possible to the original, widening their horizons and erudition. While the second book aims to control what has been read, discussion, development of forecasting skills and effective organization of speech activities based on what was read using illustrations.

XLinguae, Volume 14 Issue 1, January 2021, ISSN 1337-8384, eISSN 2453-711X 
6. The analyzed textbook Home reading in five O. Henry's short stories by M.R. Zheltukhina, A.I. Pogonova and Yu.N. Khoruzhaya (2020) contains exercises for home reading, compiled in accordance with the level of lexical and grammatical training of students of the basic level of general education. The tasks are aimed at forming a communicative competence, controlling the understanding of the text, and activating the vocabulary. Stories are selected considering the requirements for texts for home reading and the interests of secondary school students. The developed set of exercises for adapting to the level of A1 - A2 stories by O. Henry can be recommended for use in English lessons at the main level of general education as part of the curriculum, conducted online and offline in conditions of forced isolation.

7. The results of the study can be applied to improve the quality of the process of organizing home reading when teaching a foreign language in a distance learning format in the process of acquiring skills and self-work skills. The materials can be used to conduct home reading lessons at the level of basic general education as part of the school curriculum and the programs of additional educational institutions both offline and online.

\section{Acknowledgments}

The publication was carried out as a part of the programs of supporting the publication activity of the MGIMO University and the Southern Federal University.

\section{Bibliographic references}

AFANASYEVA, O.V. - MIKHEEVA, I.V. 2018. Reader of the English Language EMC. Grade 6. Moscow: Drofa. ISBN 978-5-358-19543-1.

AFANASYEVA, O.V. - MIKHEEVA, I.V. - YAZYKOVA, N.V. 2012. The English course program for EMC "English. A new English course for Russian schools. "1-5 years of study for 5-9 classes of general education institutions. Moscow: Drofa.

AFANASYEVA, O.V. - MIKHEEVA, I.V. 2014. English. Grade 6. A book for the teacher. Moscow: Enlightenment. ISBN 5-09-011050-6.

ALESHCHANOVA, I.V. - FROLOVA, N.A. - ZHELTUKHINA, M.R. 2019.

Teaching resources in professionally oriented foreign language learning. In: IOP Conf. Ser.: Mater. Sci. Eng., vol. 483(1). 012038. https://doi.org/10.1088/1757899X/483/1/012038.

ALTUN, M. 2012. Introduction and integration of innovative and information technologies in the practice of teaching English in a new type of general education school: PhD Thesis. Dushanbe: Academy of Education of Tajikistan. ISBN 978-59770-0500-5.

ARKUSOVA, I.V. 2012. Modern pedagogical technologies in teaching a foreign language (structural and logical tables and application practices). Moscow: NOU VPO MPSI.

ASIMOV, E.G. - SCHUKIN, A.N. 2009. New dictionary of methodological terms and concepts (theory and practice of teaching languages). Moscow: ICAR. ISBN 9787974-0207-7.

BATYREVA, S.G. 2017. Pedagogical conditions for the formation of communicative competence of junior schoolchildren: PhD Thesis. Moscow.

BIALYSTOK, E. 2001. Bilingualism in Development: Language, Literacy and Cognition. Cambridge: Cambridge University Press. ISBN-10: 0521635071; ISBN13: $978-0521635073$

BIM, I.L. - SHCHEPILOVA, A.V. 2010. Foreign languages. Pre-professional training of schoolchildren. 8-9 grades. Moscow: Drofa.

BIM, I.L. 2007. Specialized training in foreign languages at the senior level of a general education school. Challenges and prospects. Moscow: Enlightenment. ISBN 978-5-09-017251-6 
BUKOVSKY, S.L. 2012. Creative-oriented method of teaching oral professional communication in classes in foreign languages at a non-language university: economic profile: PhD thesis in Pedagogy: 13.00.02. Moscow: MPSU.

CEFRL. 2002. Common European Framework of Reference for Languages: Learning, Teaching, Assessment Case Studies. Strasbourg: Council of Europe Publishing, ISBN 92-871.

COYLE, D. - HOOD, PH. - MARSH, D. 2010. CLIL: Content and Language Integrated Learning. Cambridge: Cambridge University Press. ISBN 0521112982, 978-0521112987.

DORNYEI, Z. 2001.Motivational Strategies in the Language Classroom. London: Longman. ISBN 978-0-521-79029-1.

EUROPEAN COMMISSION. 2005. Europeans and Languages. A Eurobarometer Special Survey (B-1049). Brussel: European Commission, Directorate-General for Education and Culture, Vocational Training \& Language Policy.

FOKINA, K.V. - TERNOVA, L.N. - KOSTYCHEVA, N.V. 2009. Methods of teaching a foreign language. A conception of lectures. Moscow: YURITE. ISBN 9785-9916-0121-4 978-5-9692-0533-8.

GALSKOVA, N.D. - GEZ, N.I. 2007. Theory and methodology of teaching foreign languages and cultures. Moscow: Academy. ISBN 978-5-7695-6473-4.

GALSKOVA, N.D. 2003. Modern method of teaching foreign languages. Moscow: ARKTI. ISBN 5-89415-290-9

GALTSOVA, N.P. 2004. Basic categories of methods of teaching foreign languages. In: Bulletin of Tomsk State Pedagogical University, vol. 5, n. 42, pp. 73-80. ISSN 1609-624X.

GEZ, N.I. - FROLOVA, G.M. 2008. History of foreign methods of teaching foreign languages. Moscow: Academia. ISBN 978-5-7695-4653-2.

HAKUTA, K. - BUTLER, Y.G. - WITT, D. 2000. How Long Does it Take English Learners to Attain English proficiency? Santa Barbara: University of California Linguistic Minority Research Institute.

HENRY, O. 2013. Stories. Moscow: Ayres Press. ISBN: 978-5-8112-4878-0

HORNBY, A.S. - WEHMEIER, S. 2004. Oxford Advanced Learner's Dictionary of Current English. Oxford: Oxford University Press. ISBN-13: 978-0194315647; ISBN10: 0194315649 .

JACOBS, C. 2008. In search of discursive spaces in higher education. In: E. Weber (Ed.), Educational Change in South Africa: Reflections on local realities, practices and reforms. Rotterdam: Sense Publishers. ISBN: 978-90-8790-658-0.

KALISTROVA, I.D. 2003. Reading with previously removed difficulties of understanding. In: Questions of teaching oral speech and reading in a foreign language, vol. 4, pp. 23-28.

KATZMAN, N.L. 2003. Methods of teaching Latin. Moscow: Vlados. ISBN 978-5691-00982-2

KISKINA, M.V. 2017. The development of reading skills and the system of working with text in groups of students with insufficient language training in law universities. In: Bulletin of the University named after O.E. Kutafin (Moscow State University), n. 11, pp. 72-78. ISSN 2311-5998.

KITAIGORODSKAYA, G.A. 2009. Intensive foreign language training. Theory and practice. Moscow: Higher School, School of Kitaigorodskaya. ISBN 978-5-06005767-6, 978-5-87151-038-4.

KOLESNIKOVA, I.L. - DOLGINA, O.A. 2011. English-Russian terminology handbook on methods of teaching foreign languages. Moscow: Drofa. ISBN 978-5358-02636-0.

KOLKER, Y.M. - USTINOVA E.S. - ENALIEVA, T.M. 2000. Practical method of teaching a foreign language. Moscow: Academy. ISBN 5-7695-0672-5.

XLinguae, Volume 14 Issue 1, January 2021, ISSN 1337-8384, eISSN 2453-711X 
KOLKOVA, M.K. 2006. Methods of teaching foreign languages in secondary school: modernization of general education: a manual for teachers, graduate students and students. Moscow: KARO. ISBN 5-89815-426-4.

KONYSHEVA, A.V. 2005. Organization of independent work of students in a foreign language. St. Petersburg: KARO; Four quarters. ISBN 5-89815-517-1.

KONYSHEVA, A.V. 2008a. Playing foreign language learning. Theory and practice. Moscow: TetraSystems. ISBN 978-9-85470-697-9.

KONYSHEVA, A.V. 2008b. Game method in teaching a foreign language. Moscow: KARO, Four quarters. ISBN 978-5-9925-0059-2.

KONYSHEVA, A.V. 2011. Modern methods of teaching English. Moscow: TetraSystems. ISBN 978-985-536-191-7.

KOZYREVA, A.S. 2008. Types of text work in reading lessons. St. Petersburg: Science. ISBN

KUKUSHIN, V.S. 2005. Foreign languages. Creative lesson scenarios. Moscow: MarT. ISBN 5-241-00584-6.

KULAGINA, I.YU. - KOLYUTSKY, V.N. 2009. Age psychology. Moscow: KARO. ISBN 978-5-89145-075-2.

KULKINA, E.A. 2007. Methods of working with educational texts in English at the pre-text stage. In: Foreign languages at school, no. 5, pp. 74-76. ISSN 0130-6073.

KUZMENKO, O.D. - ROGOVA, G.V. Educational reading, its content and forms. In: General methodology for teaching foreign languages. Moscow: Rus. language, 1991.

LADO, R. 1964. Language Teaching. A scientific approach. New York: McGrawHill. ISBN-10: 0070357404; ISBN-13: 978-0070357402.

LISTOPAD, E.A. 2009. Improvement of the methodology for teaching foreign language to students of specialized universities based on the system of exercises in the development of creative thinking: on the material of the English language and the subject "Home reading": PhD Thesis. Moscow: MSU.

LYAPKO, D.A. 2016. Psychological and methodological foundations for the development of language grammatical competence of students in English lessons. Irkutsk: FSBOU VPO "IGLU."

MASLYKO, E.A. - BABINSKAYA, P.K. - BUDKO, A.F. - PETROVA, S.I. 2001. Table book of a foreign language teacher. Minsk: The highest school. ISBN 985-060743-2.

MILRUD, R.P. - GONCHAROV, A.A. 2003. Theoretical and practical problems of learning to understand the communicative meaning of a foreign-language text. In: Foreign languages at school, n. 1, pp. 12-18. ISSN 0130-6073.

MILRUD, R.P. 2007. English teaching methodology. English Teaching Methodology. Moscow: Drofa. ISBN 978-5-358-03288-0.

MUKHINA, B. 2012. Age psychology. Phenomenology of development. Moscow: Academy. ISBN 978-5-7695-9163-1.

OBUKHOVA, L.F. 2011. Age psychology. Moscow: Publishing House Urright; MSPP. ISBN 978-5-9916-1280-7; 978-5-94051-045-1.

OSTRIKOVA, G.N. - ZHELTUKHINA, M.R. - ZYUBINA, I.A. - SIDOROVA, I.G. 2018. Learning Via Visualization at the Present Stage of Teaching a Foreign Language. In: Astra Salvensis, vol. 4, n. 1, pp. 601-607.

PASSOV, E.I. - KUZNETSOVA, E.S. 2002. Reading training: tutorial. Moscow: Interlingua. ISBN 5-93757-015-4.

PASSOV, E.I. - KUZOVLEVA, N.E. 2011. Foreign language lesson. Moscow: Phoenix, Glossa-Press. ISBN 978-5-222-15995-8.

PASSOV, E.I. 1985. Communicative method of teaching foreign language speaking. Moscow: Enlightenment.

PAVLENKO, I.N. 2003. Use of the project methodology in the education of older preschool children. In: Foreign languages at school, n. 5, pp. 57-58. ISSN 0130-6073. 
PEROVA, G.M. 1990. On the achievement of educational goals of reading. In: Elementary school, n. 3, pp. 16-21.

POLAT, E.S. - BUKHARKINA, M.YU. - MOISEEVA, M.YU. - PETROV, A.E. 2010. Modern pedagogical and information technologies in the education system. Moscow: Academy. ISBN 978-5-7695-7057-5.

RABINOVICH, F.M. 2006. Questions of teaching oral speech and reading in a foreign language. Moscow: Higher School. ISBN

RABINOVICH, F.M. 2012. Development of speech activity in foreign language lessons. Moscow: Enlightenment. ISBN

ROGOVA, G.V. - VERESHCHAGINA, I.N. - YAZYKOVA, N.V. 2008. English language teaching methodology. Moscow: Enlightenment. ISBN 978-5-09-016636-2.

SCHUKIN, A.N. 2013. Modern intensive methods and technologies for teaching foreign languages. Moscow: Philomatis. ISBN: 978-5-98111-108-2, 978-5-98111127-3.

SCHUKIN, A.N. 2014. Foreign language training. Theory and practice. Moscow: Philomatis. ISBN 5-204-00341-X.

SCHUKIN, A.N. 2015. Methods of teaching foreign languages. Moscow: Academia. ISBN: 9785446814763.

SELIVANOVA, N.A. 2003. Literary and country studies approach to the selection of texts for home reading. In: IYASH, vol. 1, pp. 61-64. ISSN 0130-6073.

SELIVANOVA, N.A. 2004. Home reading is an important component of the content of foreign language education in high school. In: Foreign languages at school, n. 4, pp. 21-26 ISSN 0130-6073.

SHAPOVALOVA, L.I. 2010. Application of computer technologies in the process of teaching foreign languages (aspect of home reading). In: Education. Science. Innovations: southern dimension, vol. 2, n. 12, pp. 130-137. ISSN 2618-8414.

SHATILOV, S.F. 1986. Methods of teaching German in high school. Moscow: Enlightenment.

SHCHERBA, L.V. 2003. Teaching languages at school. General issues of methodology. Moscow: Academy. ISBN 5-8465-0044-7

SHEILS, J. 2001. Campaign Book of the European Year of Languages 2001. Council of Europe. Strasbourg: Modern Languages Division Council of Europe.

SKATKIN, M.N. 2002. High school didactic. Moscow: Enlightenment.

SOLOVOVA, E.N. 2005. Methods of teaching foreign languages. Basic course. Moscow: Enlightenment. ISBN 5-09-013891-5.

STACK, E.M. 2003. The Language Laboratory and Modern Language Teaching. New Jersey: Oxford University Press.

SYSOEV, P.V. - EVSTIGNEEV, M.N. 2014. How to teach a foreign language using new information and communication technologies. Moscow: Phoenix, Glossa-Press. ISBN 978-5-222-15997-2.

TAMERYAN, T.Yu. - POPOVA, T.G. - REDKOZUBOVA, E.A. - ANIKEJEVA, I.G. - SEDLIAROVA, O.M. - SOLOVYEVA, N.S. 2019. Feminine perspective of ethnic business communication. In: Espacios, vol. 40, n. 34, 18 p. ISSN: 0798-1015.

THYNE, J.M. 1963. The psychology of Learning and Techniques of Teaching. London: University of London Press.

VAN EK, J.A. - TRIM, J.L.M. 2001. Waystage 1990: Council of Europe. Cambridge: Cambridge University Press. ISBN 978-0-521-56707-7.

VAULINA, YU.E. - DOOLI, D. - PODOLYAKO, O.E. - EVANS, V. 2018. Reader of the Spotlight EMC. Moscow: Enlightenment. ISBN: 978-5-09-031471-8

VEREVKINA-RAKHALSKAYA, Yu.N. 2007. The methodology of using Internet resources in the formation of communicative competence of students of specialized universities on the material of socio-political topics: 2nd year, English: PhD Thesis. Moscow: In-t of content and methods of training RAE.

XLinguae, Volume 14 Issue 1, January 2021, ISSN 1337-8384, eISSN 2453-711X 
VISHNYAKOVA, E.A. - PYATKINA, V.E. 2019. Home reading as a means of developing foreign-language communicative competence in school. In: Scientific Almanac, vol. 2, n. 52, pp. 71-74. ISSN 2411-7609.

WACHTER, B. - MAIWORM, F. 2008. English-Taught Programmes in European Higher Education. The Picture in 2007 (ACA Papers on Cooperation in Education). Bonn: Lemmens Medien GmbH. ISBN 978-3-932306-89-1

WIILEY, T.G. 2005. Literacy and Language Diversity in the United States. McHenry: Delta Systems Co. ISBN-13: 978-1887744881; ISBN-10: 1887744886.

WONG, F.L. 2014. Individual differences in second language acquisition. In: Fillmore, C., Kempler, D., \& Wang, W. (eds) Individual Differences in Language Ability and Language Behavior. New York: Academic Press. ISBN-10: 1483238768; ISBN-13: 978-1483238760.

ZELENSKAYA, L.L. - ZUBAREVA, T.T. - DENISENKO, V.N. - CHERVYAKOVA, L.D. - KOSOVA, Yu.A. 2018. Verbal means of media manipulation with fears (on material of the American, English and Russian Tabloid Press). In: XLinguae, vol. 11, n. 3, pp. 39-50. DOI: 10.18355/XL.2018.11.03.04 ISSN 1337-8384.

ZHELTUKHINA, M.R. - POGONOVA, A.I. - KHORUZHAYA, YU.N. 2020. Home reading in five $\mathrm{O}$. Henry's short stories $=$ Home reading in short stories by $\mathrm{O}$. Henry. Volgograd: LLC "PrinTerra-Design". ISBN 978-5-98424-240-0

ZHELTUKHINA, M.R. - VIKULOVA, L.G. - MIKHAYLOVA, S.V. BORBOTKO, L.A. - MASALIMOVA, A.R. 2017. Communicative Theatre Space in the Linguistic and Pragmatic Paradigm. In: XLinguae, vol. 10, n. 2, pp. 85-100. DOI: 10.18355/XL.2017.10.02.08 ISSN 1337-8384.

ZHELTUKHINA, M.R. - ZELENSKAYA, L.L. - PONOMARENKO, E.B. 2020. Indicating success with material symbols after the collapse of the USSR. In: Visual Anthropology, vol. 33, n. 2, pp. 104-115. DOI: 10.1080/08949468.2020.1721203 ISSN 08949468.

Words: 10856

Characters: 71722 (39,85 standard pages)

Prof. Marina Rostislavovna Zheltukhina, DrSc.

Institute of Foreign Languages

Volgograd State Socio-Pedagogical University

27 Lenin Ave.

400066 Volgograd

Russia

zzmr@mail.ru

Prof. Larisa Laktemirovna Zelenskaya, PhD

School of Governance and Politics

MGIMO University

76 Prospect Vernadskogo

119454 Moscow

Russia

zelenskaya@yahoo.com

Ass. prof. Galina Nikolaevna Ostrikova, DrSc.

Socio-Humanitarian Faculty

Don State Technical University

1 Gagarin square

344000 Rostov-on-Don

Russia

galina-ostrikova@rambler.ru 
Ass. prof. Ekaterina Anatolyevna Redkozubova, DrSc.

Institute of Philology, Journalism and Cross-Cultural Communication

Southern Federal University

105/42 Bolshaya Sadovaya Street

344006 Rostov-on-Don

Russia

kateredkozubova@mail.ru

Ass. Prof. Olga Olegovna Chernova, $\mathrm{PhD}$

Foreign Languages Department

V. G. Shukhov Belgorod State Technological University

46 Kostyukova Str.

308012 Belgorod

Russia

gooll-gooll@yandex.ru 